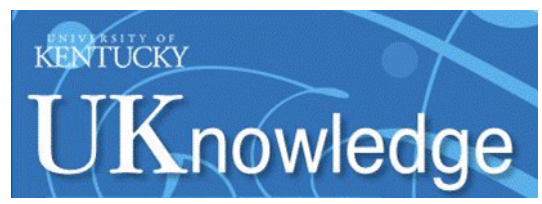

University of Kentucky

UKnowledge

7-1-2021

\title{
Content Analysis of Digital Media Coverage of the Human Papillomavirus Vaccine School-Entry Requirement Policy in Puerto Rico
}

\author{
Vivian Colón-López \\ University of Puerto Rico \\ Vilnery Rivera-Figueroa \\ University of Puerto Rico \\ Glizette O. Arroyo-Morales \\ University of Puerto Rico \\ Diana T. Medina-Laabes \\ University of Puerto Rico \\ Roxana Soto-Abreu

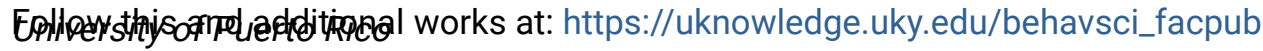 \\ Part of the Behavior and Behavior Mechanisms Commons, Health Services Administration Commons, \\ see thext palth forvicessionesearch adommons \\ Right click to open a feedback form in a new tab to let us know how this document benefits you.
}

\section{Repository Citation}

Colón-López, Vivian; Rivera-Figueroa, Vilnery; Arroyo-Morales, Glizette O.; Medina-Laabes, Diana T.; SotoAbreu, Roxana; Rivera-Encarnación, Manuel; Díaz-Miranda, Olga L.; Ortiz, Ana P.; Wells, Katelyn B.;

Vázquez-Otero, Coralia; and Hull, Pamela C., "Content Analysis of Digital Media Coverage of the Human Papillomavirus Vaccine School-Entry Requirement Policy in Puerto Rico" (2021). Behavioral Science Faculty Publications. 68.

https://uknowledge.uky.edu/behavsci_facpub/68

This Article is brought to you for free and open access by the Behavioral Science at UKnowledge. It has been accepted for inclusion in Behavioral Science Faculty Publications by an authorized administrator of UKnowledge. For more information, please contact UKnowledge@lsv.uky.edu. 


\title{
Content Analysis of Digital Media Coverage of the Human Papillomavirus Vaccine School-Entry Requirement Policy in Puerto Rico
}

\author{
Digital Object Identifier (DOI) \\ https://doi.org/10.1186/s12889-021-11311-9
}

\section{Notes/Citation Information}

Published in BMC Public Health, v. 21, article no. 1286.

(C) The Author(s) 2021

This article is licensed under a Creative Commons Attribution 4.0 International License, which permits use, sharing, adaptation, distribution and reproduction in any medium or format, as long as you give appropriate credit to the original author(s) and the source, provide a link to the Creative Commons licence, and indicate if changes were made. The images or other third party material in this article are included in the article's Creative Commons licence, unless indicated otherwise in a credit line to the material. If material is not included in the article's Creative Commons licence and your intended use is not permitted by statutory regulation or exceeds the permitted use, you will need to obtain permission directly from the copyright holder. To view a copy of this licence, visit https://creativecommons.org/licenses/by/4.0/. The Creative Commons Public Domain Dedication waiver (https://creativecommons.org/publicdomain/zero/ 1.0/) applies to the data made available in this article, unless otherwise stated in a credit line to the data.

\section{Authors}

Vivian Colón-López, Vilnery Rivera-Figueroa, Glizette O. Arroyo-Morales, Diana T. Medina-Laabes, Roxana Soto-Abreu, Manuel Rivera-Encarnación, Olga L. Díaz-Miranda, Ana P. Ortiz, Katelyn B. Wells, Coralia Vázquez-Otero, and Pamela C. Hull 


\title{
Content analysis of digital media coverage of the human papillomavirus vaccine school-entry requirement policy in Puerto Rico
}

Vivian Colón-López ${ }^{1,2^{*}}$, Vilnery Rivera-Figueroa², Glizette O. Arroyo-Morales², Diana T. Medina-Laabes', Roxana Soto-Abreu ${ }^{1}$, Manuel Rivera-Encarnación ${ }^{1}$, Olga L. Díaz-Miranda', Ana P. Ortiz ${ }^{1,3}$, Katelyn B. Wells ${ }^{4}$, Coralia Vázquez-Otero ${ }^{5}$ and Pamela C. Hull ${ }^{6}$

\begin{abstract}
Background: In August 2018, Puerto Rico (PR) became the 4th state or territory in the United States to adopt a human papillomavirus (HPV) vaccine school-entry requirement, for students 11-12 years old. Evidence suggests that the content of media coverage may impact people's perception of HPV vaccine and their willingness to vaccinate. This study aimed to analyze the content of digital news coverage related to the implementation of the policy in PR. Methods: A content review was conducted of digital media published from January 2017 through December 2018. The content reviewed was carried out in two steps: 1) creating a matrix to summarize each article's content about the policy and 2) qualitative analysis using a grounded theory approach.

Results: The search resulted in 34 articles obtained from 17 online local and international news outlets that reported the policy's implementation. Analyses showed that $61 \%$ of the news articles did not mention the number of required doses, and 79\% discussed the new policy concerning cancer prevention. In 2017, news coverage focused mostly on describing the policy, while 2018 coverage focused on controversies surrounding the implementation. Neutral emergent codes included: 1) Description of the policy; 2) Information about HPV related cancers; and 3) General information about HPV vaccine. Negative emergent codes included: 1) infringement to patient and parental autonomy; 2) Hesitancy from the political sector, and 3) Hesitancy from groups and coalitions. Positive content included: 1) knowledge and acceptance of HPV vaccine for cancer prevention; 2) importance of education and protective sexual behaviors; and 3) new vaccination law proposal.
\end{abstract}

\footnotetext{
*Correspondence: vivian.colon@upr.edu

'Puerto Rico Cancer Control and Population Sciences Division, University of

Puerto Rico Comprehensive Cancer Center, PO Box 36302, San Juan 00936-3027, Puerto Rico

${ }^{2}$ Department of Health Services Administration, Evaluation Research of Health Systems Science Program, School of Public Health, Medical Science Campus, University of Puerto Rico, PO Box 365067, San Juan 00936-5067, Puerto Rico

Full list of author information is available at the end of the article
}

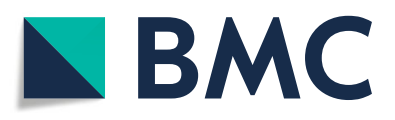

(c) The Author(s). 2021 Open Access This article is licensed under a Creative Commons Attribution 4.0 International License, which permits use, sharing, adaptation, distribution and reproduction in any medium or format, as long as you give appropriate credit to the original author(s) and the source, provide a link to the Creative Commons licence, and indicate if changes were made. The images or other third party material in this article are included in the article's Creative Commons. licence, unless indicated otherwise in a credit line to the material. If material is not included in the article's Creative Commons licence and your intended use is not permitted by statutory regulation or exceeds the permitted use, you will need to obtain permission directly from the copyright holder. To view a copy of this licence, visit http://creativecommons.org/licenses/by/4.0/ The Creative Commons Public Domain Dedication waiver (http://creativecommons.org/publicdomain/zero/1.0/) applies to the data made available in this article, unless otherwise stated in a credit line to the data. 
Conclusions: Most of the media coverage in PR was neutral and included limited information related to the vaccine, HPV, and HPV-related cancers. Neutral and negative themes could influence public concerns regarding the new policy, as well as HPV vaccination rates in PR.

Keywords: Human papillomavirus, HPV vaccine implementation, School-entry policy requirements, Content analysis, Puerto Rico

\section{Background}

High-risk types of human papillomavirus (HPV) are thought to be responsible for more than $90 \%$ of anal and cervical cancers, about $70 \%$ of vaginal, vulvar, and cancers of the oropharynx, and more than $60 \%$ of penile cancers [1]. Puerto Rico (PR), a United States (US) territory, have documented the burden of HPV infection and HPV-related cancers in this population [2-4]. Studies conducted has reported an increased risk of cervical cancer in this population (compared to mainland US), multiple barriers to cervical cancer screening $[5,6]$, low awareness of HPV and the HPV vaccine [7], increasing trends of anal cancer $[8,9]$ and a higher burden in the incidence and mortality from penile cancer in Puerto Rican men compared with other racial/ethnic groups in the US [10]. The significance of these studies led to multiple efforts from the academia, various local community coalitions, the medical community and other health professionals in PR, aiming to increase community engagement and capacity to reduce the burden of HPVassociated cancers in the island [3, 6, 10-17]. All these accomplishments led to an increase in vaccine uptake over time, and thus higher HPV vaccination rates in PR compared to mainland US.

The Healthy People 2030 goal for human papillomavirus (HPV) vaccination for adolescents is an $80 \%$ vaccination rate for the complete HPV series (Up to Date) in males and females [18]. Estimates from the $2016 \mathrm{Na}$ tional Immunization Survey (NIS), the most recent year available for PR, reported that 75.8\% (95\% CI: 70.2$80.6 \%$ ) of children ages $13-15$ years in PR had initiated the first dose of HPV vaccine, and 52.8\% (95\% CI: 46.459.0\%) were up to date with the HPV vaccine series [19]. When comparing similar estimates (initiation and up to date) with other US states and jurisdictions, PR had the 6th highest HPV vaccination rates in that year [20]. Only 10 out of 64 states and jurisdictions (including PR) had HPV initiation rates higher than $75 \%$.

School-entry requirements are an evidence-based strategy that has been proven effective for increasing coverage rates for other vaccines [21]. In August 2018, PR became the 4th US state or territory to adopt an HPV vaccine school-entry policy, adding the HPV vaccine to the list of required vaccines for school entrance for children aged 11-12 years, known as Law \#25 [22]. Three additional states and jurisdictions including
Virginia (2008), Washington DC (2009) and Rhode Island (2015) had previously required the HPV vaccine for school entry, and Hawaii subsequently adopted a requirement as of July 2020; although the scope of all the policies enacted so far varies regarding sex, age and number of doses required [23]. Virginia and Washington DC passed the laws through a legislative process, while Rhode Island, PR and Hawaii took a regulatory approach using the authority of the Department of Health.

Studies evaluating the impact of HPV vaccine school entry requirements in Virginia, DC and Rhode Island on vaccination rates have been inconsistent [24, 25], likely due to differences in exemption and enforcement provisions, organizational factors, and parental noncompliance $[26,27]$. Countries with successful vaccination programs have acknowledged the importance of monitoring the media as it might shift perceptions and parental motivations to vaccinate, even in the context of a school requirement [28]. The media has been documented as the second most significant source (after health care providers) of information for parents to make vaccination decisions [29]. Documentation of how HPV school entry policies and controversy about them are covered in the news media can help understand the context in which the policies are implemented and in which parents make decisions to comply with the policy or not.

\section{Methods}

The aim of this study was to examine the content of online news coverage related to the HPV vaccine schoolentry requirement in PR before and after the first year of the implementation.

\section{Data collection}

A systematic search was conducted using Google (www. google.com/pr) to locate digital media reports related to the HPV vaccination policy and its implementation in PR from January 2017 to December 2018. Reputable online news sources (such as: endi.com, elvocero.com, metropr.com, noticel.com) who comply with the criteria of reliable sources [30] were included in the analysis. The following search terms (in Spanish) were used to identify the online coverage reports: virus de papiloma humano (human papillomavirus), VPH (HPV), vacuna OR vacunación contra VPH (vaccine OR HPV vaccine), 
implementación (implementation), Puerto Rico (PR). Only articles that address the HPV school entry policy were included in the analysis. Most of the articles reviewed were from outlets in Puerto Rico and written in Spanish; only one was in English. Other exclusion criteria and analysis performed are presented in Fig. 1.

\section{Data analysis}

A series of steps were performed. First, a classification matrix was developed by the research team to identify if the selected news articles contained information regarding: (a) the policy enactment date and (b) groups impacted by the policy (e.g. age group, sex), (c) doses required for the HPV vaccine, the d) HPV vaccine prevention messages (e.g. cancer prevention), and the (e) groups cited (e.g. coalitions, Government agencies). Second, using a modified grounded theory approach [31], members of the research team identified emergent themes in the data. A codebook with definitions of each of the codes identified as well as the main themes was developed. We used the qualitative data analysis software Atlas.ti (version 8) to facilitate data manipulation and retrieval during analysis. To identify the key themes, coders independently read the transcripts and identify the data by tone (level 1), sub themes (level 2) and codes (level 3) (Fig. 2). Research staff discussed conceptual differences regarding coding terminology and established a common set of codes [32]. All points of disagreement were resolved through discussion before the remaining articles were analyzed. We compared the frequency of text excerpt by tone and year using the Pearson's chi-square test. The tests were 2-sided with 0.05 significance levels. The analyses were performed using Stata version 14.1 software (StataCorp LP, College Station, TX). This study was approved by the IRB of the University of Puerto Rico Medical Sciences Campus.

\section{Results}

\section{Search results}

Throughout January 2017 to December 2018, a total of 66 news articles were found referring to the search terms used. Only 35 articles satisfied our inclusion criteria by

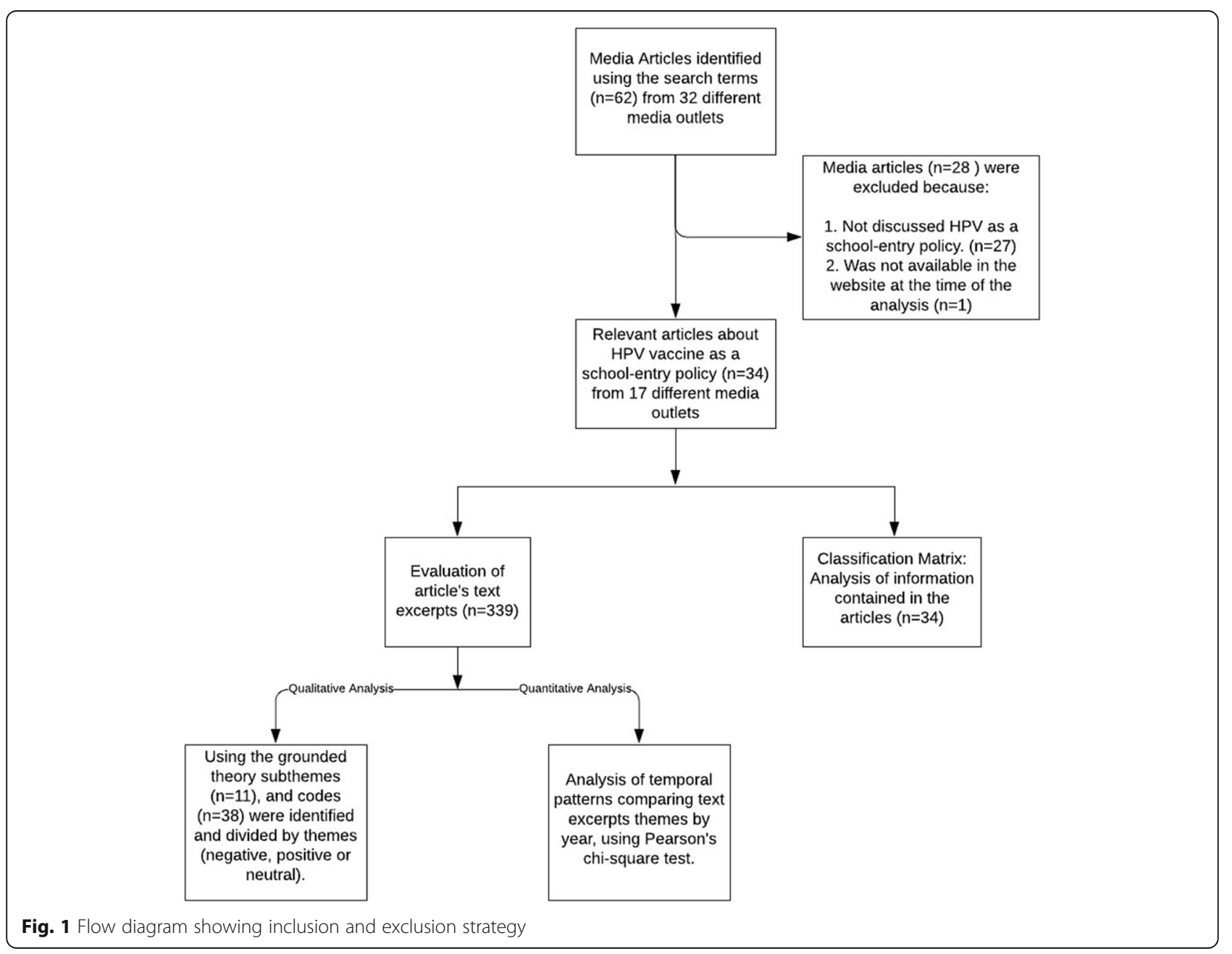




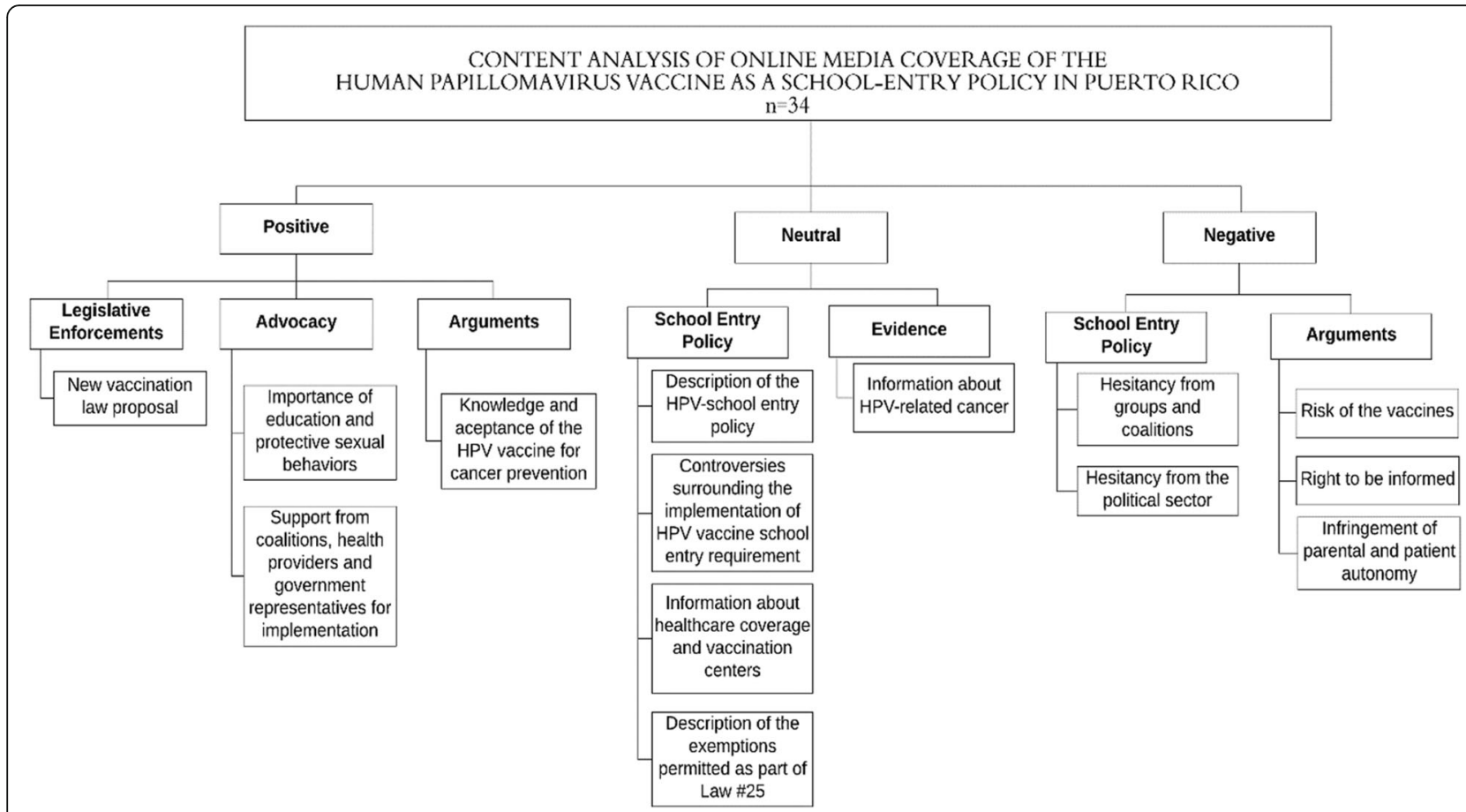

Fig. 2 Most emergent codes and subthemes by tones

focusing on the school-entry policy, and one of these was not accessible at the time of the analysis $(N=34)$. Figure 1 summarizes the selection of the news articles and analysis derived from articles studied. A total of 18 (53.0\%) news articles were gathered in 2017 and 16 (47.0\%) from 2018.The search resulted in 17 online local and international media outlets that reported on news related to the HPV school-entry requirement in PR.

\section{Descriptive characteristics of article content}

Descriptive information about the content of the news articles $(n=34)$ derived from the classification matrix is shown in Table 1. Almost all the news articles reported the date in which the HPV vaccine school-entry requirement took effect (91.2\%). More than half of the news articles included information about cervical cancer (58.8\%), while other HPV-related cancers were mentioned less often (11.8 to 23.5\%). Most articles highlighted the importance of the vaccine for cancer prevention (79.4\%), while around a quarter of the articles discussed HPV as a sexually transmitted infection (STI) (26.4\%). Most of the articles did not discuss the number of doses needed to complete the immunization series (38.2\% included this information); likewise, information regarding the accessibility of the vaccine was not provided frequently (23.5\%). Government agency representatives, followed by coalitions and groups against the implementation, were mostly cited as spokesperson.

\section{Neutral media}

Most of the media reports published were neutral (58.6\%), being the most emergent: (1) description of the HPVschool entry policy; (2) information about HPV-related cancers; (3) general information about the HPV vaccine; (4) information about health care coverage and vaccination centers; (5) controversies surrounding the implementation of HPV vaccine school-entry requirement; and (6) description of the exemptions permitted as part of Law \#25. The PR Secretary of Health was the most common spokesperson who disseminated this information. Other news articles provided data from governmental or cancer registry sources, highlighting the burden of cervical cancer and the disparities in cervical cancer incidence in PR in comparison to mainland US. They also stated that these data were fundamental reasons for the decision to implement the HPV vaccine school-entry requirement. Fig. 2 shows the subthemes and the most emerging codes.

\section{Description of the policy (11.8\%)}

Most of the neutral text excerpts disseminated in the media described the policy's announcement when it was going to take place and the required ages.

"All students between the ages of 11 and 12 must be vaccinated against the Human Papilloma Virus (HPV) by next year, the government of Puerto Rico ordered on Monday."

-Journalist 
Table 1 Content of the Online Media Articles Analyzed Regarding HPV Vaccine School-Entry Requirement: $2017-2018$ ( $n=34$ Articles)

\begin{tabular}{|c|c|c|}
\hline Topics discussed & $\mathbf{N}$ & $\begin{array}{l}\text { Percent } \\
\text { (\%) }\end{array}$ \\
\hline \multicolumn{3}{|l|}{ HPV-associated cancers } \\
\hline Cervical cancer & 20 & 58.8 \\
\hline Oropharyngeal cancer & 8 & 23.5 \\
\hline Penile cancer & 7 & 20.6 \\
\hline Vulvar/vaginal cancer & 7 & 20.6 \\
\hline Anal cancer & 4 & 11.8 \\
\hline Effective date of mandate & 31 & 91.2 \\
\hline Number of doses that are recommended for complete HPV vaccination & 13 & 38.2 \\
\hline Concerns about the efficacy and safety of the vaccine & 19 & 55.9 \\
\hline Highlighted the importance of the vaccine for cancer prevention & 27 & 79.4 \\
\hline Referred to HPV as a STI & 9 & 26.5 \\
\hline Information regarding HPV vaccine accessibility and health coverage & 8 & 23.5 \\
\hline \multicolumn{3}{|l|}{ Groups Cited } \\
\hline Coalitions Groups Against the Implementation & 11 & 32.4 \\
\hline Government Agency Representatives & 29 & 85.3 \\
\hline Health Professionals & 10 & 29.4 \\
\hline Data and Statistics Institutes & 14 & 41.2 \\
\hline Coalitions Groups In favor of the Implementation & 4 & 11.8 \\
\hline Others & 3 & 8.8 \\
\hline
\end{tabular}

\section{Information about HPV related cancers (9.4\%)}

Other text excerpts provided data from governmental or cancer registry sources, highlighting the burden of cervical cancer and the disparities in cervical cancer incidence in PR versus mainland US, and stated that these data were fundamental reasons for the decision to implement the HPV vaccine school-entry requirement.

\section{Controversies surrounding the implementation of HPV vaccine school-entry requirement (5.6\%)}

Results from the content analysis highlighted controversies a year prior to the implementation, with disagreement among groups in favor of and against the HPV vaccine school-entry requirement. This text excerpts discuss the arguments that questioned the implementation of the HPV vaccine as a requirement and the lack of compliance with the policy.

"The vaccine against human papillomavirus (HPV) stirred controversy again since its release to the market 12 years ago, a period in which groups in favor and against [the vaccine] have deliberated on its benefits and risks."

- Journalist

"On the one hand, some people applaud the Department of Health initiative so that boys and girls of 11 and 12 years old are inoculated against this disease, after being included in the list of vaccines required for school entry as of August 2018. However, others question the government's obligation to promote a vaccine that they classify as unsafe and effective due to the experience observed in other countries. Adverse effects have been reported and created organizations of parents against it."

- Journalist

\section{Description of the exceptions process (4.7\%)}

These text excerpts discussed details regarding the exemption process, explaining that PR only accepts medical and religious exemptions provided via a vaccine exemption affidavit that has to be submitted to the child's school [22].

"The Secretary of Health ... said the measure applies to both public and private schools. Parents may disregard the measure for medical or religious reasons if they present an affidavit or a medical certificate." -Journalist

Other neutral codes discussed information regarding coverage of the cost of vaccination through the Vaccine for Children (VFC) Program and accessibility of the vaccine via the government health insurance program (5.9\%). Lastly, neutral themes referred to the 
recommendation of HPV vaccine together with other vaccines (i.e., recommending the HPV vaccine in the same way and at the same visit as Tdap and meningococcal vaccines) (1.5\%).

\section{Negative media}

The most common emerging negative codes are the following: 1) infringement of parental and patient autonomy; 2) hesitancy from the political sector (e.g. legislators); 3) hesitancy from groups and coalitions; 4) risk of the vaccine (safety and efficacy); and 5) right to be informed.

\section{Infringement of parental and patient autonomy}

A total of $17(5.0 \%)$ of the excerpts studied discussed this code, being one of the most emergent topics within negative media. Overall, articles reported negative views towards the mandate of the vaccine (not HPV vaccination itself).

... "vaccines against HPV are a tool for cervical cancer prevention; however, the vaccine should not be mandatory. These stories were mostly presented by coalitions and organizations spokespersons in which they described the need to respect parental autonomy with regards to medical decision-making for their children".

-Spokesperson from local coalitions statement

\section{Hesitancy from groups and coalitions (5.0\%)}

The negative tone codes highlighted the hesitancy of various groups against the new HPV vaccine school entry policy, which stated different reasons for their hesitancy (Table 2). Some of the groups were not against vaccines, but they expressed hesitation against the mandate.

\section{Risk of the vaccine (safety and efficacy) (2.9\%)}

Worry about vaccine safety and discussion of the secondary effects associated with the HPV vaccine were also discussed in the online media outlets. This concern was mostly expressed by coalition groups against the implementation of this vaccination policy.
"This project [1303] does not even mention the risks inherent to vaccination. [When you] read [the project] it seems that the vaccines are made from holy water,"

-Quote from local coalition spokesperson against HPV school-entry requirement

"We are greatly concerned about the lack of orientation on the risks of vaccination. This practice leads to an uninformed or dishonorable consent [without the proper orientation] can put risk health and life at risk", said the organizers.

-Quote from local coalition spokesperson against HPV school-entry requirement

Information in the news articles noted that the HPV vaccines are a cervical cancer prevention tool; however, they highlighted opinions of some groups that the vaccine should not be mandatory (3.8\%). In summary, those coalitions, and groups state that each family, after being properly informed about the vaccine's advantages and risks, should freely decide which of these strategies they want to assume for them and their family health.

"[This requirement] needs to be assessed carefully. If it is proven [that the vaccine] is effective and safe, I don't see any problems as long as [this requirement] will not surpass parental choice".

-Spokesperson of a family organization against HPV school entry requirement

\section{Right to be informed (2.7\%)}

Like the prior code, most of the interviewee were not against the HPV vaccine but acknowledged the importance of advocating for understanding the risk and benefits of the vaccine and discussed the right of the parents to be informed.

"We are not against vaccines, but what is being [administered] to our children has benefits and risks. It is our right as parents to be informed". -Local coalition spokesperson against HPV school entry requirement

Table 2 Groups against the HPV vaccine school-entry requirement and their reasons

\begin{tabular}{ll}
\hline Group & Reasons against HPV vaccine school-entry requirement \\
\hline Family coalition & The vaccine only protects against the most common virus strains and questions its effectiveness. \\
Feminist groups & $\begin{array}{l}\text { Did not object to the vaccine but question the obligatory nature of the policy since the vaccine has been } \\
\text { controversial. Recommend that it be accompanied by vaccine education and sex education. State that each } \\
\text { family must decide freely in their health strategies. }\end{array}$ \\
$\begin{array}{l}\text { Local coalitions against HPV school } \\
\text { entry requirement }\end{array}$ & $\begin{array}{l}\text { Violates the rights of parents in deciding on the care of their children, and they have the right to be } \\
\text { informed of the risks of any medical treatment. They understand that the government is obstructing } \\
\text { education with this requirement given the high number of vaccines that are imposed annually as part of } \\
\text { the school-entry policy and support of the } 1576 \text { bill }\end{array}$ \\
\hline
\end{tabular}




\section{Positive media}

Four codes emerged that were positive in tone in the online articles: 1) knowledge and acceptance of the HPV vaccine for cancer prevention; 2) importance of education and protective sexual behaviors; 3) new vaccination law proposal; and 4) support from coalitions, health providers and government representatives for implementation.

\section{Knowledge and acceptance of the HPV vaccine for cancer prevention (3.8\%)}

Many positive tone text excerpts presented prior to and after the implementation of the HPV vaccine schoolentry requirement in $\mathrm{PR}$ addressed the importance of HPV vaccination for cancer prevention.

"I understand that this is something positive because it is a vaccine that has been used since 2006 in Puerto Rico and the United States ... a vaccine that is going to prevent cancer, a very common cancer, that when you see the data it affects many of our patients. It has a very great burden on our patients, so I understand that it is a positive thing."

-Pediatrician

The importance of educate the population of the benefits of this vaccine were documented.

"The message that must be given to the people of Puerto Rico, is that [HPV related cancers] are totally preventable. When you get vaccinated, it prevents the development of cancer, and as I said before, we have to protect our children, our adolescents"

- Department of Health Representative

"Yes, a lot of people don't make the link between the virus and cancer. What they have to understand is that it is a vaccine that prevents cancer, it is extraordinary ..."

-News Reporter

\section{New vaccination law proposal (1.8\%)}

Misleading information about the HPV vaccine mandate was disseminated in the media about the bill 1303 (a legislative proposal in $\mathrm{PR}$ which was intended to create a new law for children and students aiming to strengthen disease prevention through vaccination among these groups [33]). The quotes were unclear if they were in effect talking about the new bill proposed 1303 or the HPV school-entry requirement that would be effective in August 2017.

Support from coalitions, health providers and government representatives for implementation (1.5\%)

Statements that stressed the importance of HPV vaccination were mostly driven by personal support of the vaccine, whereas coalitions, and other medical and community-based organizations emphasized the importance of this vaccine school-entry requirement for cancer prevention, addressing the burden of HPV and HPVrelated cancers in their messages.

"Experts urge parents to vaccinate their children by the beginning of the 2017-2018 school year and, if so, complete the corresponding vaccination processes, according to a press release for PR Vaccination Coalition and HPV Advisory Panel."

-Journalist

\section{Temporal patterns}

Across the 17 articles studied, a total of 339 text excerpts were coded as having a positive, negative, and neutral theme. There were some excerpts that had more than one theme (mixed theme). Figure 3 shows a distribution of the themes by year. For both years (2017 and 2018), the highest proportion of text excerpts were neutral (61.7 and 55.5\%, respectively) towards the HPV vaccine school-entry requirement, followed by negative themes. In 2018, we observed an increase of $0.9 \%$ on negative themes compared with 2017. No significant differences across the years were observed by themes $(p>$ $0.05)$.

\section{Discussion}

Previous research has documented how mass media might influence public risk perceptions and decisions about immunization and HPV, but few have examined the context before and prior the implementation of an HPV school entry requirement [28, 29, 34-37]. The results from our study showed that although information regarding the HPV vaccine school-entry requirement was disseminated prior and during the implementation, most of the information during this period was neutral. Changes in themes during this period as well as controversies during the two-year period of the enactment might have led to confusion of the public about the implementation of this mandate.

Content analysis of the media's representation of the HPV vaccine worldwide demonstrates that the themes associated with the vaccine are variable, ranging from negative to neutral to positive [38-42]. A notable aspect from the media discourse in PR before and after the $\mathrm{HPV}$ vaccine school-entry requirement was that media coverage appeared to be more neutral in content than in most countries. Although it is important to acknowledge that the methodology used in different studies varies, a study conducted in Romania showed that (28.0\%) of the media reports were negative, in the US $14.4 \%$ of the media content reported had a similar tone, and a study in Japan which studied newsprint media reported $23.3 \%$ 


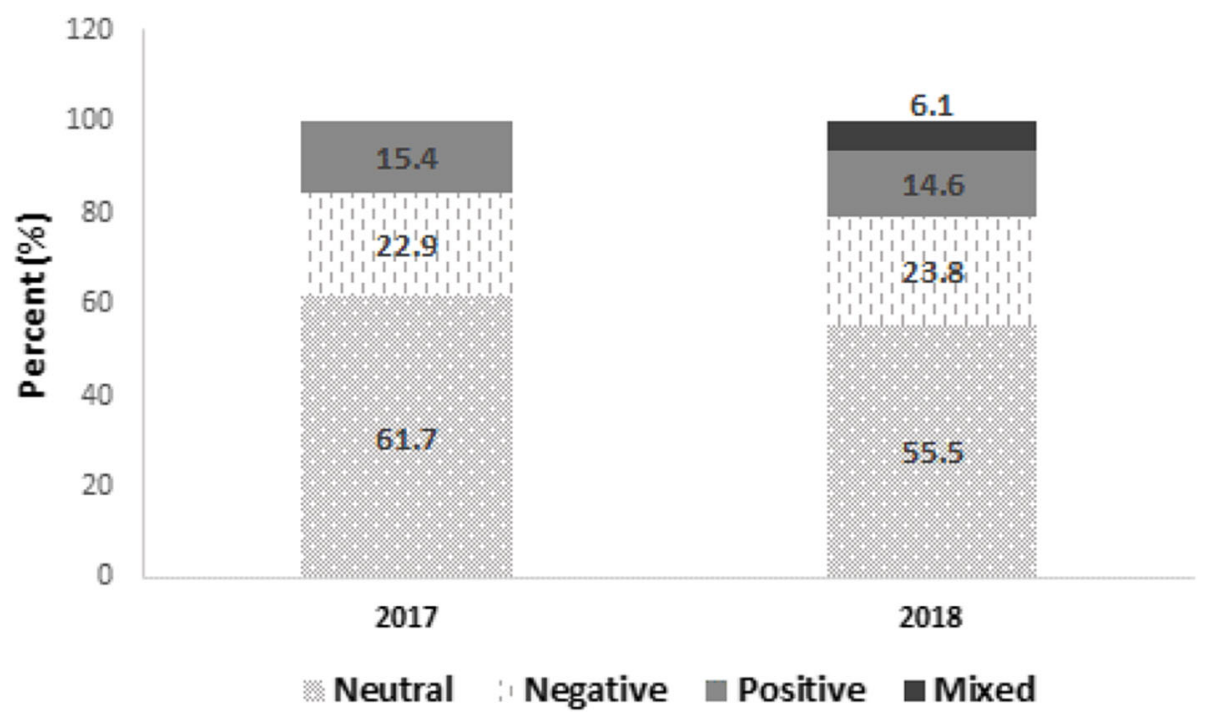

Fig. 3 Distribution of theme $(n=339)$ from news articles related to HPV vaccine school-entry requirement in PR

[42-44]. Most of the negative context of the themes analyzed in our study were driven towards the risk of the vaccine, infringement to patient autonomy, right to be informed, and lack of education about HPV and the vaccine. Similar findings were noted in a another study, were concerns regarding vaccine safety and parent's right to choose, were commonly cited as arguments against the HPV vaccine school-entry requirement [45]. Another study explored news coverage in states and jurisdictions in which the mandate was implemented, highlighted similar topics [46]; and discussed how this discourse might negatively impact the HPV vaccine school-entry requirement but the adolescent immunization schedule as well.

It was noted in our study that the $\mathrm{DOH}$ provided most of this neutral content. Scientists or academics were not included as part of this discussion, which might have been a missed opportunity that could have brought robust positive statements in favor of the vaccine and the mandate [47]. Movement in opposition mostly stress HPV vaccine safety, patient and parent autonomy rights; those are legitimately issues that can be promoted in educational campaigns and the media. When compared to anti-vax movements worldwide, although similar in scope, the magnitude and impact of these groups on Puerto Rico might differ, which could translate in higher HPV vaccine acceptance rates prior to the requirement and in the increase in other vaccine-preventable diseases as well [48-50].

Our analysis showed a shift in the content of the online media from informational (neutral) prior to the implementation to a negative content of information from a coalition against the implementation. This shift was probably driven by the one-year lag period, which was led to promote the new HPV vaccine school-entry requirement. During this period, legislators requested hearings to be informed regarding the safety and efficacy of the vaccine. Since PR's immunization law authorizes the Secretary of Health to require vaccinations for school-entry, the participation of the Legislature seems to have brought confusion and provoked controversies regarding the implementation of the HPV vaccine school-entry requirement. This also led to the development of a bill, which included philosophical exceptions [51]. Although this later bill (1576) was not approved, this period and the mixed information disseminated by the media at the time of the HPV vaccine school-entry requirement might have triggered confusion about the actual implementation.

This study adds to the literature on the main themes disseminated prior to the implementation of HPV vaccine school-entry requirements, using PR as an example, and to research on the media coverage of mandates, which may in fact, create a backlash to governmentsponsored public health programs [46]. However, this study had some limitations. We used a selection of only online news articles focused on HPV vaccine mandates rather than including articles where the HPV vaccine was mentioned, limiting the analysis without news focusing only in HPV and HPV vaccine, which could affect the amount of news with positive and/or neutral content. Also, the small sample of online news articles reviewed might limit the depth of the qualitative analysis of the data, and robustness of the interpretation. This understandably make this initial effort worth of a prospective evaluation of content analysis several points after the implementation of the school-entry requirement. The timeframe established for inclusion criteria to 
gather the news, which was less than 24 months, and the fact that the media coverage was focused on the school entry policy for HPV vaccination, could also have affected the sample size. Most of the previous studies had an extended timeframe (more than two years) and had a broader HPV-related coverage search [46]. Existing search databases were considered for content analysis. However, since access to these databases was restricted and required additional cost and registration (e.g., LexisNexis), and might not contain a broad array of news content in Spanish; we continued with the analysis of digital newspapers with free access. In addition to this, in September 2017, Hurricane Maria harmed the dissemination and publication of information in the news media due to the state of emergency in PR. Nonetheless, the HPV vaccine requirement and legislative activity after the implementation started as planned.

Despite these limitations, this effort of understanding the context of the media regarding news related to the HPV vaccine school-entry requirement implementation in important for future public health efforts, particularly given recent changes to the requirement entering the 2019 academic period (expanding to 11-14 years old during the 2019-2020 academic period). However, this decision was also later impacted by environmental disasters in January 2020 (earthquake and continuous seismic activity primarily in the South-west of the island) and the COVID-19 pandemic that might have impacted immunization uptake, hesitation towards the HPV vaccine and might change the narrative and online media discourse on immunization.

\section{Conclusion}

This study explored the content of online media prior and during the first year of implementation of PR's HPV vaccine school-entry requirement. Vaccine safety and autonomy concerns were common. Detailed information about the vaccine school-entry requirement as well as education on the importance of this policy for the prevention of HPV-related cancers was frequently missing, which could lead to an incomplete picture or lack of understanding of the public health importance of this mandate. Due to the impact that media can have on important immunization strategies, continued monitoring and active participation of coalitions and scientists in favor of these mandates are important. Scientists and providers should insert in the discussion developing content to disseminate the benefits of the vaccine, specifically to neutralize the negative content. Other media sources, such as radio, television, blogs, podcasts, among others, can contribute another aspect or a different level of acceptance to analyze how this content in the analysis can influence the perspective of users related to the HPV vaccine. Future research should continue to monitor news media depictions of the HPV vaccine to assess which themes or controversies remain a pronounced theme of coverage or whether the media ultimately presents the HPV vaccine as an important routine public health service.

\section{Abbreviations}

HPV: Human papilomavirus; VPH: Virus del papiloma humano; PR: Puerto Rico; US: United States; NIS: National Immunization Survey; STI: Sexually transmitted infections

\section{Acknowledgments}

This publication was supported by the Comprehensive Cancer Center of the UPR (a public corporation of the Government of Puerto Rico created in virtue of Law 230 of August 26, 2004 as amended). The content is entirely the responsibility of the authors and does not necessarily represent the official views of the Comprehensive Cancer Center UPR.

\section{Authors' contributions}

VCL: Funding acquisition, Supervision, Conceptualization, Methodology, Writing-original draft preparation, Investigation, Validation; VRF: Methodology, Writing-original draft preparation, formal analysis and investigation; GOAM: Methodology, Writing-original draft preparation, formal analysis and investigation; DTML: formal analysis, investigation, Writing- Reviewing and Editing RSA: formal analysis, investigation, Writing- Reviewing and Editing; MERE: Reviewing: OLDM: formal analysis, investigation, Writing- Reviewing and Editing; APO: Funding acquisition, formal analysis, investigation, Writing- Reviewing and Editing; KBW: Funding acquisition, methodology, Writing- Reviewing and Editing; CVO: Methodology, Writing-original preparation, reviewing and editing and PCH: Funding acquisition, formal analysis, investigation, WritingReviewing and Editing. The author(s) read and approved the final manuscript.

\section{Funding}

This work was supported by the National Cancer Institute/National Institute of Health [grant numbers 5R01CA232743] for the Comprehensive Cancer Center of the University of Puerto Rico, Medical Sciences Campus; and the Cancer Prevention Fellowship from the $\mathrm{NCl}$ and Harvard T.H. Chan School of Public Health - NIH [grant number 2T32CA057711-26].

Availability of data and materials

The datasets used and/or analyzed during the current study are available from the corresponding author on reasonable request.

\section{Declarations}

\section{Ethics approval and consent to participate}

Ethical approval for the Implementation of School Entry Policies for Human Papillomavirus Vaccination (HPV-PIVac) was secured from the University of Puerto Rico Medical Sciences Campus- Institutional Review Board (Protocol \#A8060218)..

\section{Consent for publication}

Not applicable.

\section{Competing interests}

VCL has received compensation from Merck and Co., Inc. for consultancy in June 2020. APO received compensation from Merck and Co., Inc. in October 2019 for consultancy.

\section{Author details}

${ }^{1}$ Puerto Rico Cancer Control and Population Sciences Division, University of Puerto Rico Comprehensive Cancer Center, PO Box 36302, San Juan 00936-3027, Puerto Rico. ² Department of Health Services Administration, Evaluation Research of Health Systems Science Program, School of Public Health, Medical Science Campus, University of Puerto Rico, PO Box 365067 , San Juan 00936-5067, Puerto Rico. ${ }^{3}$ Department of Biostatistics and Epidemiology, Graduate School of Public Health, Medical Sciences Campus, University of Puerto Rico, PO Box 70184, San Juan 00936-8184, Puerto Rico. ${ }^{4}$ Association of Immunization Managers, 620 Hungerford Dr. Suite 29, 
Rockville, MD 20850, USA. ${ }^{5}$ Harvard T.H. Chan School of Public Health Dana-Farber Cancer Institute, NCl Postdoctoral Fellow, 450 Brookline Ave., LW 633, Boston, MA 02215, USA. 'Department of Behavioral Science, College of Medicine, Markey Cancer Center, University of Kentucky, 2365 Harrodsburg Rd, Suite A230, Lexington, KY 40504-3381, USA.

Received: 27 August 2020 Accepted: 18 June 2021

Published online: 01 July 2021

\section{References}

1. Szymonowicz KA, Chen J. Biological and clinical aspects of HPV-related cancers. Cancer Biology and Medicine. 2020. https://doi.org/10.20892/j.issn.2 095-3941.2020.0370.

2. Ortiz AP, Tortolero-Luna G, Romaguera J, Pérez CM, González D, Muñoz C, et al. Seroprevalence of HPV 6, 11, 16 and 18 and correlates of exposure in unvaccinated women aged 16-64 years in Puerto Rico. Papillomavirus Res. 2018;5:109-13. https://doi.org/10.1016/j.pvr.2018.03.006.

3. Ortiz AP, Tamayo V, Scorsone A, Soto-Salgado M, Febo I, Piovanetti P, et al. Prevalence and correlates of cervical HPV infection in a clinic-based sample of HIV-positive Hispanic women. Papillomavirus Res. 2017;4:39-44. https:// doi.org/10.1016/j.pvr.2017.06.006.

4. Ortiz AP, Romaguera J, Pérez CM, González D, Muñoz C, González L, et al. Prevalence, genotyping, and correlates of anogenital HPV infection in a population-based sample of women in Puerto Rico. Papillomavirus Res. 2016;2:89-96. https://doi.org/10.1016/j.pvr.2016.04.002.

5. Pérez CM, González-Barrios D, Ramos-Cartagena JM, Ortiz AP. Association of body mass index with adherence to cervical Cancer screening recommendations in Hispanic women. J Low Genit Tract Dis. 2020;24(1):1420. https://doi.org/10.1097/LGT.0000000000000504.

6. Ortiz AP, Hebl S, Serrano R, Fernandez ME, Suarez E, Tortolero-Luna G. Factors associated with cervical cancer screening in Puerto Rico. Prev Chronic Dis. 2010;7(3) https://pubmed.ncbi.nlm.nih.gov/20394697/.

7. Fernández ME, Le YCL, Fernández-Espada N, Calo WA, Savas LS, Vélez C, et al. Knowledge, attitudes, and beliefs about human papillomavirus (HPV) vaccination among Puerto Rican mothers and daughters, 2010: a qualitative study. Prev Chronic Dis. 2014;11. https://doi.org/10.5888/pcd11.140171.

8. Ortiz AP, Ortiz-Ortiz KJ, Traverso-Ortiz M, Ríos MY, Colón-López V, Palefsky JM. Anal cancer trends in Puerto Rico from 1985 to 2005: the potential impact of the AIDS epidemic. AIDS Patient Care STDs. 2014;28(4):165-7. https://doi.org/10.1089/apc.2013.0365.

9. Acevedo-Fontánez Al, Suárez E, Torres Cintrón CR, Ortiz AP. Risk of anal Cancer in women with a human papillomavirus-related gynecological neoplasm. J Low Genit Tract Dis. 2018;22(3):225-30. https://doi.org/10.1097/ LGT.0000000000000395.

10. Colón-López V, Ortiz AP, Soto-Salgado M, Torres-Cintrón M, Pettaway CA, Puras-Báez A, et al. Penile cancer disparities in Puerto Rican men as compared to the United States population. Int Braz J Urol. 2012;38(6):72838. https://doi.org/10.1590/1677-553820133806728.

11. Colón-López V, Ortiz AP, Del Toro-Mejías LM, García H, Clatts MC, Palefsky J. Awareness and knowledge of human papillomavirus (HPV) infection among high-risk men of Hispanic origin attending a sexually transmitted infection (STI) clinic. BMC Infect Dis. 2012;12(1). https://doi.org/10.1186/14 71-2334-12-346.

12. Colón-López V, Ortiz AP, Palefsky J. Burden of human papillomavirus infection and related comorbidities in men: implications for research, disease prevention and health promotion among hispanic men. Vol. 29. P R Health Sci J. 2010;29(3):232-40 https://pubmed.ncbi.nlm.nih.gov/20799510/.

13. Colón-López V, Ortiz AP, Soto-Salgado M, Torres-Cintrón M, Mercado-Acosta JJ, Suárez E. Anal cancer incidence and mortality in Puerto Rico. P R Health Sci J. 2013;32(2):76-81 https://pubmed.ncbi.nlm.nih.gov/23781623.

14. Colon-Lopez V, Ortiz AP, Soto-Salgado M, Torres-Cintrón M, Perez N, Mercado-Acosta JJ, et al. Survival from anal cancer among Hispanics Puerto Rico, 2000-2007. J Gastrointest Cancer. 2014;45(2):234-8. https://doi. org/10.1007/s12029-014-9607-x.

15. Ortiz AP, Pérez-Irizarry J, Soto-Salgado M, Suárez E, Pérez N, Cruz M, et al. Human papillomavirus-related cancers among people living with AIDS in Puerto Rico. Prev Chronic Dis. 2014;11. https://doi.org/10.5888/pcd11.130361.

16. Romaguera J, Caballero-Varona D, Tortolero-Luna G, Marrero E, Suárez E, Pérez CM, et al. Factors associated with HPV vaccine awareness in a population-based sample of hispanic women in Puerto Rico. J Racial Ethn
Health Disparities. 2015;3(2):281-90. https://doi.org/10.1007/s40615-0150144-5.

17. Ortiz AP, Soto-Salgado M, Calo WA, Tortolero-Luna G, Perez CM, Romero CJ, et al. Incidence and mortality rates of selected infection-related cancers in Puerto Rico and the United States. Infect Agent Cancer. 2010;5(1). https:// doi.org/10.1186/1750-9378-5-10.

18. Healthy People 2030. Increase the proportion of adolescents who get recommended doses of the HPV vaccine-IID-08. Office of Disease Prevention and Health Promotion. https://www.health.gov/healthypeople/ objectives-and-data/browse-objectives/vaccination/increase-proportion-a dolescents-who-get-recommended-doses-hpv-vaccine-iid-08. Accessed 11 Jun 2021.

19. Walker TY, Elam-Evans LD, Singleton JA, Yankey D, Markowitz LE, Fredua B, et al. National, Regional, State, and Selected Local Area Vaccination Coverage Among Adolescents Aged 13-17 Years — United States, 2016. MMWR Morb Mortal Wkly Rep. 2017. https://doi.org/10.15585/mmwr. mm6633a2.

20. Centers for Disease Control and Prevention (CDC). 2016 Adolescent Human Papillomavirus (HPV) Vaccination Coverage Report 2016. https://www.cdc. gov/vaccines/imz-managers/coverage/teenvaxview/data-reports/hpv/ reports/2016.html. Accessed 30 Apr 2021.

21. Community Preventive Services Task Force. What Works Fact Sheet: Increasing Appropriate Vaccination. https://www.the communityguide.org/resources/wha t-works-increasing-appropiate-vaccination. Accessed 15 Mar 2020.

22. Ley de las Inmunizaciones Compulsorias a los Niños Pre-escolares y Estudiantes en el Estado Libre Asociado de Puerto Rico. https://agencias.pr. gov/ogp/Bvirtual/leyesreferencia/PDF/Edcaci\%C3\%B3n\%20(k012)/25-1983/ 25-1983.pdf. Accessed 30 Apr 2021.

23. National Conference of States Legislatures. HPV Vaccine: State Legislation and Statutes.https://www.ncsl.org/research/health/hpv-vaccine-state-legisla tion-and-statutes.aspx\#. Accessed 4 Mar 2020.

24. Thompson EL, Livingston MD, Daley EM, Zimet GD. Human papillomavirus vaccine initiation for adolescents following Rhode Island's school-entry requirement, 2010-2016. Am J Public Health. 2018;108(10):1421-3. https:// doi.org/10.2105/AJPH.2018.304552.

25. Perkins RB, Lin M, Wallington SF, Hanchate AD. Impact of school-entry and education mandates by states on HPV vaccination coverage: analysis of the 2009-2013 National Immunization Survey-Teen. Hum Vaccines Immunother. 2016;12(6):1615-22. https://doi.org/10.1080/21645515.2016.1150394.

26. Omer SB, Richards JL, Ward M, Bednarczyk RA. Vaccination policies and rates of exemption from immunization, 2005-2011. N Engl J Med. 2012;367(12): 1170-1. https://doi.org/10.1056/NEJMc1209037.

27. Salmon DA, Omer SB, Moulton LH, Stokley S, Dehart MP, Lett S, et al. Exemptions to school immunization requirements: the role of school-level requirements, policies, and procedures. Am J Public Health. 2005;95(3):43640. https://doi.org/10.2105/AJPH.2004.046201.

28. Suppli CH, Hansen ND, Rasmussen M, Valentiner-Branth P, Krause TG, Mølbak K. Decline in HPV-vaccination uptake in Denmark - the association between HPV-related media coverage and HPV-vaccination. BMC Public Health. 2018;18(1):1360. https://doi.org/10.1186/s12889-018-6268-x.

29. Teoh D. The power of social media for HPV vaccination-not fake news! Am Soc Clin Oncol Educ B. 2019;(39):75-8. https://doi.org/10.1200/edbk_239363.

30. University of California Merced Library. Reputable News Sources - Web Evaluation \& News Sources - LibGuides at University of California Merced. https://libguides.ucmerced.edu/news/reputable. Accessed 29 Apr 2021.

31. Krueger R, Casey M. Focus groups: a practical guide for applied research. Thousand Oaks, CA: Sage Publications; 2009.

32. Kelly BJ, Leader AE, Mittermaier DJ, Hornik RC, Cappella JN. The HPV vaccine and the media: how has the topic been covered and what are the effects on knowledge about the virus and cervical cancer? Patient Educ Couns. 2009;77(2):308-13. https://doi.org/10.1016/j.pec.2009.03.018.

33. Cámara de Representantes. P. de la C. 1303. 2017. p. 1-28. https://tucamara pr.org/dnncamara/Documents/Measures/050dabee-61ed-4009-b5d3-601ca1 e81d80.pdf. Accessed 3 May 2021.

34. Oubari $H$, Tuttle R, Rath B, Bravo L. Communicating vaccine safety to the media and general public. Curr Drug Saf. 2015;10(1):80-6. https://doi.org/1 $0.2174 / 157488631001150407111312$.

35. Rousseau C, Moreau N, Dumas MP, Bost I, Lefebvre S, Atlani-Duault L. Public media communications about H1N1, risk perceptions and immunization behaviours: a Quebec-France comparison. Public Underst Sci. 2015:24(2): 225-40. https://doi.org/10.1177/0963662513495149. 
36. Hilton S, Hunt K, Langan M, Bedford H, Petticrew M. Newsprint media representations of the introduction of the HPV vaccination programme for cervical cancer prevention in the UK (2005 - 2008). Soc Sci Med. 2010;70(6): 942-50. https://doi.org/10.1016/j.socscimed.2009.11.027.

37. Abdelmutti N, Hoffman-Goetz L. Risk messages about HPV, cervical cancer, and the HPV vaccine Gardasil in north American news magazines. In: Journal of Cancer Education Springer. 2010;25(3):451-6. https://doi.org/10.1 007/s13187-010-0087-9.

38. Dunn AG, Leask J, Zhou X, Mandl KD, Coiera E. Associations between exposure to and expression of negative opinions about human papillomavirus vaccines on social media: an observational study. J Med Internet Res. 2015;17(6):e144. https://doi.org/10.2196/jmir.4343.

39. Margolis MA, Brewer NT, Shah PD, Calo WA, Gilkey MB. Stories about HPV vaccine in social media, traditional media, and conversations. Prev Med (Baltim). 2019;1 18:251-6. https://doi.org/10.1016/j.ypmed.2018.11.005.

40. Briones $R$, Nan X, Madden $K$, Waks $L$. When vaccines go viral: an analysis of HPV vaccine coverage on YouTube. Health Commun. 2012;27(5):478-85. https://doi.org/10.1080/10410236.2011.610258.

41. Keelan J, Pavri V, Balakrishnan R, Wilson K. An analysis of the human papilloma virus vaccine debate on MySpace blogs. Vaccine. 2010;28(6): 1535-40. https://doi.org/10.1016/j.vaccine.2009.11.060.

42. Habel MA, Liddon N, Stryker JE. The HPV vaccine: a content analysis of online news stories. J Women's Health. 2009;18(3):401-7. https://doi.org/10.1089/jwh.2008.0920.

43. Penta MA, BĂban A. Mass media coverage of HPV vaccination in Romania: A content analysis. Health Educ Res.2014 Dec 1 [cited 2021 Jun 14]; 29(6): 977-92. Available from:https://pubmed.ncbi.nlm.nih.gov/24890190/

44. Ueda N, Yokouchi R, Onoda T, Ogihara A. Characteristics of Articles About Human Papillomavirus Vaccination in Japanese Newspapers: Time-Series Analysis Study. JMIR Public Heal Surveill. 2017 Dec 19 [cited 2021 Jun 14]; 3(4):e97. Available from: https://pubmed.ncbi.nlm.gov/29258972/

45. Vazquez-Otero $\mathrm{C}$. Understanding the adoption process of an HPV vaccine school-entry requirement in Puerto Rico. PhD dissertation. Vol. 23. University of South Florida;2019.https://scholarcommons.usf.edu/cgi/viewcontent.cgi?a rticle=9617\&context=etd. Accessed 3 May 2021.

46. Casciotti DM, Smith KC, Andon L, Vernick J, Tsui A, Klassen AC. Print news coverage of school-based human papillomavirus vaccine mandates. J Sch Health. 2014:84(2):71-81. https://doi.org/10.1111/josh.12126.

47. Gollust SE, LoRusso SM, Nagler RH, Fowler EF. Understanding the role of the news media in HPV vaccine uptake in the United States: synthesis and commentary. Hum Vaccin Immunother. 2016;12(6):1430-4. https://doi.org/1 0.1080/21645515.2015.1109169.

48. Odone A, Ferrari A, Spagnoli F, Visciarelli S, Shefer A, Pasquarella C, et al. Effectiveness of interventions that apply new media to improve vaccine uptake and vaccine coverage. Hum Vaccin Immunother. 2015;11(1):72-82. https://doi.org/10.4161/hv.34313.

49. Larson HJ, Wilson R, Hanley S, Parys A, Paterson P. Tracking the global spread of vaccine sentiments: the global response to Japan's suspension of its HPV vaccine recommendation. Hum Vaccin Immunother. 2014;10(9): 2543-50. https://doi.org/10.4161/21645515.2014.969618.

50. Okuhara T, Ishikawa H, Okada M, Kato M, Kiuchi T. Amount of narratives used on Japanese Pro- and Anti-HPV vaccination websites: A content analysis. Asian Pac J Cancer Prev. 2018. https://doi.org/10.22034/APJCP.2018.19.10.2691.

51. Cámara de Representantes. P. de la C. 1576. 2018. p. 1-7. https://www.tuca marapr.org/dnncamara/Documents/Measures/3f6d45e5-5c46-4dfe-a9b3-e3 684a55ce40.pdf. Accessed 3 May 2021.

\section{Publisher's Note}

Springer Nature remains neutral with regard to jurisdictional claims in published maps and institutional affiliations.

Ready to submit your research? Choose BMC and benefit from:

- fast, convenient online submission

- thorough peer review by experienced researchers in your field

- rapid publication on acceptance

- support for research data, including large and complex data types

- gold Open Access which fosters wider collaboration and increased citations

- maximum visibility for your research: over $100 \mathrm{M}$ website views per year

At BMC, research is always in progress.

Learn more biomedcentral.com/submissions 